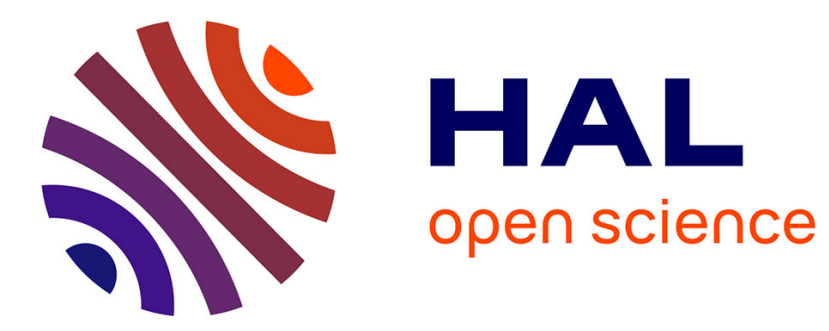

\title{
New pigments from the terrestrial cyanobacterium Scytonema sp. collected on the Mitaraka inselberg, French Guyana
}

\author{
Valérie Bultel-Poncé, Fabienne Félix-Théodose, Corinne Sarthou, \\ Jean-François Ponge, Bernard Bodo
}

\section{To cite this version:}

Valérie Bultel-Poncé, Fabienne Félix-Théodose, Corinne Sarthou, Jean-François Ponge, Bernard Bodo. New pigments from the terrestrial cyanobacterium Scytonema sp. collected on the Mitaraka inselberg, French Guyana. Journal of Natural Products, 2004, 67 (4), pp.678-681. 10.1021/np034031u . hal$00367057 \mathrm{v} 2$

\section{HAL Id: hal-00367057 \\ https://hal.science/hal-00367057v2}

Submitted on 18 Aug 2010

HAL is a multi-disciplinary open access archive for the deposit and dissemination of scientific research documents, whether they are published or not. The documents may come from teaching and research institutions in France or abroad, or from public or private research centers.
L'archive ouverte pluridisciplinaire HAL, est destinée au dépôt et à la diffusion de documents scientifiques de niveau recherche, publiés ou non, émanant des établissements d'enseignement et de recherche français ou étrangers, des laboratoires publics ou privés. 


\title{
New Pigments from the Terrestrial Cyanobacterium Scytonema sp. \\ Collected on the Mitaraka Inselberg, French Guyana
}

\author{
V. Bultel-Poncé,$^{* \dagger}$ F. Felix-Theodose ${ }^{\dagger}$ C. Sarthou, ${ }^{\dagger}$ J.-F. Ponge, ${ }^{\ddagger}$ and B. Bodo ${ }^{\dagger}$
}

Unité de Chimie et Biochimie des Substances Naturelles Associée au CNRS, Muséum National d'Histoire Naturelle, 63 Rue Buffon, 75005 Paris, France, and Unité d'Ecologie Générale Associée au CNRS, Muséum National d'Histoire Naturelle, 4 Avenue du Petit Château, 91800 Brunoy, France

\begin{abstract}
Inselbergs are hills rising abruptly from the surrounding plains where cyanobacteria are the only living organisms under conditions of intense solar radiation. A survival mechanism to prevent UV-damage has been associated with synthesis of the ultraviolet-screening, photostable sheath pigment scytonemin. The organic extract of Scytonema sp., collected on the Mitaraka inselberg, French Guyana, yielded three new pigments, tetramethoxyscytonemin (1), dimethoxyscytonemin (2), and scytonine (3), derived from the scytoneman skeleton of scytonemin. These structures were assigned mainly on the basis of $1 \mathrm{H}$ and $13 \mathrm{C}$ NMR and MS experiments.
\end{abstract}

Cyanobacteria have drawn attention for their ability to produce an immense number and variety of bioactive secondary metabolites, ranging from notorious toxins to potential therapeutic agents. They are an ancient, diverse group of microorganisms and are able to inhabit and thrive in an incredible variety of environments

Inselbergs are isolated rocks, mountains, or groups of mountains (the so-called "island mountains") rising abruptly from the surrounding plains in humid (forest) to semiarid (savanna) locations. They are often dome-shaped, consisting of granite and gneiss, partially covered by a thin layer of organic substrates. They possess a unique vegetation that differs in species composition from that of the surroundings.

In an ongoing program devoted to the study of plant succession, we investigated the Mitaraka inselberg in French Guyana, in particular granite-collected samples where cyanobacteria are the only living organisms under conditions of intense solar radiation. The survival ability of cyanobacteria under these specific conditions

\footnotetext{
${ }^{*}$ To whom correspondence should be addressed. Tel: 3314079 5608. Fax: 3314079 3135. E-mail: bultel@ mnhn.fr.

${ }^{\dagger}$ Chimie et Biochimie des Substances Naturelles.

* Ecologie Générale.
} 
to prevent UV-damage has been associated with synthesis of the ultraviolet screening, photostable sheath pigment scytonemin. ${ }^{1}$

Scytonemin is a yellow-brown dimeric pigment with potent ultraviolet-absorbing properties, located in the extracellular polysaccharide sheath of some cyanobacteria, characterized by Proteau and co-workers in 1993. ${ }^{2}$ To date, it is the only sunscreen pigment identified from this series. The occurrence of scytonemin restricted to cyanobacteria is widespread among this diverse group, and more than 300 species with sheaths colored with yellow to brown pigments have been described. ${ }^{3,4}$ Instead of scytonemin, some cyanobacteria contain a red to purple pigment, gloeocapsin, whose structure remains unknown. The production of such molecules can be related to those of other known sunscreens, such as mycosporin-like amino acids in phytoplankton and fungi, ${ }^{5}$ animal melanins, ${ }^{6}$ and plant phenylpropanoids. ${ }^{7,8}$

We report, herein, the structure of three new pigments, 1-3, related to the scytoneman skeleton. These molecules derive from condensation of tryptophanyl- and tyrosylderived subunits with a linkage between these units unique among natural products. Compound $\mathbf{1}$ has been termed tetramethoxyscytonemin; compound $\mathbf{2}$, dimethoxyscytonemin; and compound $\mathbf{3}$, scytonin. Their isolation and structure determination is now presented.

The intensly colored compounds exhibited typical spectroscopic properties of scytonemin. ${ }^{1}$

The 1H NMR spectrum (Table 1) of purple compound $\mathbf{1}\left(\mathrm{C}_{40} \mathrm{H}_{34} \mathrm{~N}_{2} \mathrm{O}_{8}\right.$ by HRFABMS) indicated two tertiary methyl groups resonating as singlets at $\delta 2.95$ and 3.15, a singlet for a methine at $\delta 4.65$, a typical $\mathrm{AB}$ system for a para-substituted phenol with a hydroxyl proton at $\delta 9.23$, and signals for one disubstituted indole ring and an $\mathrm{NH}$ protonat $\delta 12.12$.

The ${ }^{13} \mathrm{C}$ NMR spectrum showed a carbonyl signal at $\delta 203.0$, a methine at $\delta 85.3$, a quaternary carbon at $\delta$ 84.5, and two methoxy signals at $\delta 52.4$ and 56.6. Among the aromatic carbons was observed an olefinic quaternary carbon signal at $\delta 157.1$, indicating a phenol function. Owing to the molecular formula indicating 40 carbons and the relatively simple aspect of both its ${ }^{1} \mathrm{H}$ and ${ }^{13} \mathrm{C}$ NMR spectra, compound $\mathbf{1}$ has several elements of symmetry.

2D-NMR analysis led to the structural assignment of the molecule. Starting from the long-range correlations of $\mathrm{H}-11 / \mathrm{H}-15$, we were able to link the para-substituted phenol to the $\mathrm{CH}-9$ bearing a methoxy. A second spin system was built from $\mathrm{HMBC}$ correlations of $\mathrm{H}-9$ with $\mathrm{C}-2$, C-3 bearing $\mathrm{O}-\mathrm{CH}_{3}-17, \mathrm{C}-3 \mathrm{a}$, and C-10. $\mathrm{H}_{3}-17$ showed long-range correlations with $\mathrm{C}-3$ and C-9. The disubstituted indole ring was established by COSY 
and $\mathrm{HMBC}$ correlations of $\mathrm{H}-5$ to $\mathrm{H}-8$ and the long-range correlations observed for $\mathrm{H}-4$ with C-3a, C-4a, C-8a, and $\mathrm{C}-8 \mathrm{~b}$. The remaining two quaternary carbons, $\mathrm{C}-1$ and $\mathrm{C}-1$ ', provided the connection between the two dimeric units. The geometry of the tetrasubstituted olefin in $\mathbf{1}$ is predicted as $E$ by inspection of molecular models and was confirmed as the lower isomer by MM2 calculation.

The ${ }^{1} \mathrm{H}$ NMR spectrum (Table 2) of the dark red compound $2\left(\mathrm{C}_{38} \mathrm{H}_{28} \mathrm{~N}_{2} \mathrm{O}_{6}\right.$ by HRFABMS) indicated two tertiary methyl groups resonating as singlets at $\delta 3.05$ and 3.18, a singlet for a methine at $\delta 4.56$, two typical $\mathrm{AB}$ systems for para-substituted phenols with two hydroxyl protons at $\delta 9.28$ and 10.28 , and signals for two disubstituted indole rings and two $\mathrm{NH}$ protons at $\delta 10.60$ and 12.18 . The ${ }^{13} \mathrm{C} \mathrm{NMR}$ spectrum showed two carbonyls at $\delta 194.5$ and 199.7, a methine at $\delta$ 84.6, a quaternary carbon at $\delta 102.2$, and two methoxy groups at $\delta$ 50.9 and 56.4. Among the aromatic carbons, there were two olefinic quaternary carbons at 157.1 and $160.1 \mathrm{ppm}$ (bearing the phenol functions) and two olefinic carbons at $\delta 144.2$ and 130.6. Detailed 2D-NMR analysis led to the full assignment of two parts of the molecule. The first part of the molecule was assigned as in $\mathbf{1}$. The second part was built, starting from the H-11/H-15 signal, observing HMBC correlations with the quaternary olefinic C3 and with $\mathrm{C}-10$, in addition to those of $\mathrm{H}-9$ with $\mathrm{C}-11 / 15, \mathrm{C}-3$, and the carbonyl $\mathrm{C}-2$. The indole ring was established by the COSY and HMBC correlations of proton H-5 to H-8 and the long-range correlations observed for NH-4 with C-3a, C-4a, C-8a, and C-8b. The E-configuration of the 3-9 double bond was deduced by observing NOESY correlation between H-11/H-15 and H-12/H-14 and NH-4.

As in $\mathbf{1}$, the remaining two quaternary carbons (C-1 and C-1') provided the connection between the dimeric units. The geometry of the tetrasubstituted olefin in compound 2 was predicted to be $E$ by inspection of molecular models and was confirmed as the lower isomer by MM2 calculation.

The $1 \mathrm{H}$ NMR spectrum (Table 3 ) of the brown compound $3\left(\mathrm{C}_{31} \mathrm{H}_{22} \mathrm{~N}_{2} \mathrm{O}_{6}\right.$ by HRFABMS) indicated two tertiary methyl groups resonating as singlets at $\delta 3.55$ and 3.65, a singlet for an olefinic methine at $\delta 7.67$, signals of a typical $\mathrm{AB}$ system for a para-substituted phenol with a hydroxyl proton at $\delta 9.35$, and signals for disubstituted indole rings and two NH protons at $\delta 11.24$ and 11.62.

The first disubstituted indole ring was established by the COSY and HMBC correlations of protons H-5 to H-8. Using the long-range correlations observed for H-4 with a quaternary carbon at $\delta 150.7$ and a carbonyl at 170.2, we were able to locate $\mathrm{C}-2$ and $\mathrm{C}-3$, respectively. 
Starting from the long-range correlations of $\mathrm{H}-11 / \mathrm{H}-15$, we were able to link the para-substituted phenol to the olefinic CH-9. A second spin system was built by the HMBC correlations of H-9 with C-2', C-3'a, $\mathrm{C}-15$, and $\mathrm{C}-3$ ' bearing the carbonyl $\mathrm{C}-2$ ', in addition to $\mathrm{CH} 3-17$ protons showing long-range correlations with the carbonyl C-2'. The disubstituted indole ring was established by the COSY and HMBC correlations of proton H-5' to H-8' and the long-range correlations observed for H-4' with C-2, C-3'a, C-4'a, C-8'a, and C-8'b. The second part of the molecule was constituted and linked to the first indole ring owing to the HMBC correlation observed for NH-4' with C-2.

The E-configuration of the 3'-9 double bond was deduced from NOE data (NOESY experiment) particularly the correlation between the methoxy protons H3-17 and H-9 and the correlation between H-11/H-15 and $\mathrm{H}-12 / \mathrm{H}-14$ and NH-4'.

A possible route for biosynthesis of compound $\mathbf{3}$, starting from reduced scytonemin, is proposed. The first step consists of loss of one para-substituted phenol unit. The cyclopentenone rings may then be opened, and successive methoxylation can occur before cyclization.

Scytonemin demonstrated interesting anti-inflammatory activity in a model of PMA-induced mouse ear edema and anti-proliferative activity by the inhibition of rhPKC $\beta 1$ activity. ${ }^{9}$

Compounds 1-3 were tested for their cytotoxicity (KB cells); they were atoxic even at $10^{-5} \mathrm{M}$. These compounds did not inhibit the growth of the Gram-positive bacterium Staphylococcus aureus (ATCC 6538), the Gram-negative Escherishia coli (ATCC 8739), and the fungi Candida tropicalis (IP 201.73) even at $1 \mu \mathrm{M}$.

\section{Experimental Section}

General Experimental Procedures. IR spectra were recorded on a Nicolet FTIR in $\mathrm{MeOH} .{ }^{1} \mathrm{H}$ and ${ }^{13} \mathrm{C}$ NMR spectra were obtained on a Bruker Avance 400 spectrometer with standard pulse sequences operating at 400 and $100 \mathrm{MHz}$, respectively; the chemical shift values are reported as $\delta$ (ppm units) and the coupling constants in Hz. $J_{\text {mod }}$, NOESY, HSQC (optimized for $\left.{ }^{1} J_{\mathrm{CH}}\right) 140 \mathrm{~Hz}$ ), and HMBC $\left({ }^{n} J_{\mathrm{CH}}=7 \mathrm{~Hz}\right.$ ) experiments were recorded using standard Bruker pulse sequences. ESI-QqTOF spectra were acquired in positive mode on a QStar Applied Biosystem. HRMS (positive mode) were measured on a JEOL 700 spectrometer. Si gel CC was carried out using Kieselgel 60 (230-400 mesh, E. Merck), and RP-18 gel CC was carried out using Polygoprep 
60-50 (Macherey-Nagel). Fractionations were monitored by TLC using aluminium-backed sheets (Si gel 60 F254, $0.25 \mathrm{~mm}$ thick and RP-18WUV 254 , Macherey-Nagel, $0.25 \mathrm{~mm}$ thick) with visualization at 254 and $366 \mathrm{~nm}$ and Liebermann, or phosphomolybdic acid, spray reagent. All solvents were distilled. Semipreparative reversedphase HPLC (Akzo Nobel RP-18 column, 7.5 x 250 mm) was performed with a L-6200A pump (Merck-Hitachi) equipped with an L-4250C UV-vis detector (Merck-Hitachi) and a D-2500 chromato-integrator (Merck-Hitachi).

Biological Material. The cyanobacterium Scytonema sp. was collected in the dry state in March 2001, on the Mitaraka inselberg (Tumuc Hamac) in French Guyana, and stored in the dark at room temperature. This cyanobacterium grows on granite as colonies, i.e., as mats with an area of several square centimeters even under full sunlight in semiarid habitats. The material was identified by Prof. Couté, and a specimen is deposited at Museum National d'Histoire Naturelle (Paris, France, no. SC2002). The crust consists of a close association between soil mineral particles and cyanobacteria, living on granite substrate; a minute collection yielded several samples of Scytonema sp. The crusts constitute the first step before the development of humus and provides niches for the establishment by seed of several plant species.

Extraction and Isolation. Extraction of SC2002 with $\mathrm{CH}_{2}-\mathrm{Cl}_{2} / \mathrm{MeOH}(\mathrm{v} / \mathrm{v})$ yielded $2 \mathrm{~g}$ of crude material. Purification of this extract by chromatography over a silica gel column $\left(\mathrm{CH}_{2}-\mathrm{Cl}_{2}\right.$ to $\left.\mathrm{MeOH}\right)$ led to two fractions containing pigments eluted with $10 \% \mathrm{MeOH}$ in $\mathrm{CH}_{2} \mathrm{Cl}_{2}$. Repeated chromatographic separations of the first, over RP18 TLC, afforded 1 and 3. Compound $\mathbf{1}(6.3 \mathrm{mg})$ eluted with $40 \%$ TFA $0.1 \%$ in MeCN, $R_{f} 0.56$. Elution of the fraction $R_{f} 0.40$ obtained after the first TLC purification with $20 \%$ TFA $0.1 \%$ in $\mathrm{MeOH}$ yielded compound $\mathbf{3}, R_{f} 0.42(4.6 \mathrm{mg})$.

The second pigments-containing fraction was subjected to open column reversed-phase RP-18 and semipreparative reversed-phase HPLC (Akzo Nobel RP-18 column, 7.5 x 250 mm, 2 mL/min 50\% TFA 0.1\% in $\mathrm{MeCN} ; \lambda=386 \mathrm{~nm})$, accomplishing the separation and final purification of $2(5.6 \mathrm{mg})$ eluted at $t_{\mathrm{R}} 21 \mathrm{~min}$.

Tetramethoxyscytonemin (1): purple amorphous solid; UV (MeOH) $\lambda_{\max } \mathrm{nm}(\varepsilon), 212$ (35928), 562 (5944); IR (MeOH) 3652, 3541, 2978, 2831, 1696, 1514, 1448, 1413, 1025; ${ }^{1} \mathrm{H}$ and ${ }^{13} \mathrm{C}$ NMR data, see Table 1; ESI-QqTOF-MS $m / z[M+\mathrm{H}]+671 ; \mathrm{m} / \mathrm{z}[\mathrm{M}+\mathrm{Na}]+693 ; \mathrm{m} / \mathrm{z}[\mathrm{M}+\mathrm{K}]+709 ;$ FABHRMS $\mathrm{m} / \mathrm{z}[\mathrm{M}+\mathrm{H}]+$ 671.2396 (calcd for $\mathrm{C}_{40} \mathrm{H}_{35} \mathrm{~N}_{2} \mathrm{O}_{8}, 671.2384$ ).

Dimethoxyscytonemin (2): dark red amorphous solid; UV (MeOH) $\lambda_{\max } \mathrm{nm}(\varepsilon), 215$ (60354), 316 (18143), 422 (23015); IR (MeOH) 3662, 3533, 2970, 2900, 2878, 1695, 1602, 1452, 1401, 1025; ${ }^{1} \mathrm{H}$ and ${ }^{13} \mathrm{C}$ 
NMR data, see Table 2; ESI-QqTOF-MS m/z $[\mathrm{M}+\mathrm{H}]+609 ; \mathrm{m} / z[\mathrm{M}+\mathrm{Na}]+631 ; \mathrm{m} / z[\mathrm{M}+\mathrm{K}]+647$;

FABHRMS $m / z[\mathrm{M}+\mathrm{H}]+609.2025$ (calcd forC ${ }_{38} \mathrm{H}_{29} \mathrm{~N}_{2} \mathrm{O}_{6}, 609.2018$ ).

Scytonine (3): brown amorphous solid; UV (MeOH) $\lambda_{\max } \mathrm{nm}(\varepsilon), 207$ (38948), 225 (37054), 270 (22484); IR (MeOH) 3661, 3536, 2971, 2878, 1690, 1602, 1510, $1440 \mathrm{~cm}-1 ;{ }^{1} \mathrm{H}$ and ${ }^{13} \mathrm{C}$ NMR data, see Table 3; ESI-QqTOF-MS $m / z[\mathrm{M}+\mathrm{H}]+519 ; \mathrm{m} / z[\mathrm{M}+\mathrm{Na}]+541 ; \mathrm{m} / z[\mathrm{M}+\mathrm{K}]+557 ; \mathrm{FABHRMS} m / z[\mathrm{M}+\mathrm{H}]+$ 519.1564 (calcd for $\mathrm{C}_{31} \mathrm{H}_{23} \mathrm{~N}_{2} \mathrm{O}_{6}, 519.1550$ ).

Acknowledgment. We thank Prof. Couté, Laboratoire de Cryptogamie, MNHN (Paris, France), for the cyanobacterium identification, C. Caux and A. Blond for $400 \mathrm{MHz}$ NMR spectra, and J.-P. Brouard and L. Dubost for the MS analyses. The Région Ile de France is gratefully acknowledged for funding the $400 \mathrm{MHz}$ NMR and QqTOF spectrometers used in this work.

\section{References and Notes}

(1) Garcia-Pichel, F.; Sherry, N. D.; Castenholz, R. Photochem. Photobiol. 1992, 56, 17-23.

(2) Proteau, P. J.; Gerwick, W. H.; Garcia-Pichel, F.; Castenholz, R. Experientia 1993, 49, 825-829.

(3) Garcia-Pichel, F.; Castenholz, R. J. Phycol. 1991, 27, 395-409.

(4) Edwards, H. G. M.; Garcia-Pichel, F.; Newton, E. M.; Wynn-Williams, D. D. Spectrochim. Acta Part A 2000, 56, 193-200.

(5) Sinha, R. P.; Klisch, M.; Gro“niger, A.; Hader, D. P. J. Photochem. Photobiol. 1998, 47, 83-94.

(6) Kollias, N.; Sayre, R. M.; Zeise, L.; Chedekel, M. R. J. Photochem. Photobiol. B Biol. 1991, 9, 135160.

(7) Takahashi, A.; Takeda, K.; Ohnishi, T. Plant Cell Physiol. 1991, 32, 541-547.

(8) Tevini, M.; Braun, J.; Fieser, G. Photochem. Photobiol. 1991, 53, 329-334. 
(9) Stevenson, C. S.; Capper, E. A.; Roshak, A. K.; Marquez, B.; Grace, K.; Gerwick, W. H.; Jacob, R. S.; Marshall, L. A. Inflamm. Res. 2002, 51, 112-114. 


\section{Legends of figures}

Figure 1. Proposed biosynthetic pathway for 3 . 
Table 1. ${ }^{1} \mathrm{H}$ and ${ }^{13} \mathrm{C}$ NMR Data for $\mathbf{1}$ in DMSO- $d_{6}{ }^{a}$

\begin{tabular}{lll}
\hline no. & $\delta^{1} \mathrm{H}(\mathrm{m}, J \mathrm{~Hz})$ & $\delta^{13} \mathrm{C}$ \\
\hline 1 & & 122.0 \\
2 & & 203.0 \\
3 & & 84.5 \\
$3 \mathrm{a}$ & & 143.3 \\
4 & $12.12(\mathrm{~s}, 1 \mathrm{H})$ & \\
$4 \mathrm{a}$ & & 140.2 \\
5 & $7.05(\mathrm{~d}, 8.1,1 \mathrm{H})$ & 125.3 \\
6 & $7.25(\mathrm{ddd}, 7.6,7.6,1.1,1 \mathrm{H})$ & 123.4 \\
7 & $7.15(\mathrm{ddd}, 7.6,7.6,0.9,1 \mathrm{H})$ & 119.9 \\
8 & $7.54(\mathrm{~d}, 8.1,1 \mathrm{H})$ & 112.6 \\
$8 \mathrm{a}$ & & 122.1 \\
$8 \mathrm{~b}$ & & 126.9 \\
9 & $4.65(\mathrm{~s}, 1 \mathrm{H})$ & 85.3 \\
10 & & 125.7 \\
11 & $6.67(\mathrm{~m}, 8.6,1 \mathrm{H})$ & 129.4 \\
12 & $6.45(\mathrm{~m}, 8.6,1 \mathrm{H})$ & 114.7 \\
13 & & 157.1 \\
14 & $6.45(\mathrm{~m}, 8.6,1 \mathrm{H})$ & 114.7 \\
15 & $6.67(\mathrm{~m}, 8.6,1 \mathrm{H})$ & 129.4 \\
16 & $9.23(\mathrm{~s}, 1 \mathrm{H})$ & \\
17 & $2.95(\mathrm{~s}, 3 \mathrm{H})$ & 52.4 \\
18 & $3.15(\mathrm{~s}, 3 \mathrm{H})$ & 56.6 \\
\hline$a{ }^{1} \mathrm{H} 400 \mathrm{MHz} ;{ }^{13} \mathrm{C} 100 \mathrm{MHz} ; 298 \mathrm{~K}$. &
\end{tabular}


Table 2. ${ }^{1} \mathrm{H}$ and ${ }^{13} \mathrm{C}$ NMR Data of 2 in DMSO- $d_{6}{ }^{a}$

\begin{tabular}{|c|c|c|}
\hline no. & $\delta^{1} \mathrm{H}(\mathrm{m}, J \mathrm{~Hz})$ & $\delta{ }^{13} \mathrm{C}$ \\
\hline 1 & & 123.0 \\
\hline 2 & & 194.5 \\
\hline 3 & & 144.2 \\
\hline $3 a$ & & 132.2 \\
\hline 4 & $12.18(\mathrm{~s}, 1 \mathrm{H})$ & \\
\hline $4 a$ & & 122.7 \\
\hline 5 & $7.38(\mathrm{~d}, 7.9,1 \mathrm{H})$ & 127.5 \\
\hline 6 & $7.28(\mathrm{dd}, 7.9,7.4,1 \mathrm{H})$ & 122.1 \\
\hline 7 & $7.35(\mathrm{dd}, 7.3,6.3,1 \mathrm{H})$ & 125.5 \\
\hline 8 & $7.58(\mathrm{~d}, 7.6,1 \mathrm{H})$ & 123.3 \\
\hline $8 \mathrm{a}$ & & 124.3 \\
\hline $8 \mathrm{~b}$ & & 127.7 \\
\hline 9 & $7.09(\mathrm{~s}, 1 \mathrm{H})$ & 130.6 \\
\hline 10 & & 134.3 \\
\hline 11 & $7.21(\mathrm{~m}, 8.4,1 \mathrm{H})$ & 129.6 \\
\hline 12 & $6.92(\mathrm{~m}, 8.4,1 \mathrm{H})$ & 116.3 \\
\hline 13 & & 160.1 \\
\hline 14 & $6.92(\mathrm{~m}, 8.4,1 \mathrm{H})$ & 116.3 \\
\hline 15 & $7.21(\mathrm{~m}, 8.4,1 \mathrm{H})$ & 129.6 \\
\hline 16 & $10.28(\mathrm{~s}, 1 \mathrm{H})$ & \\
\hline 1 & & 123.2 \\
\hline 2 & & 199.7 \\
\hline 3 & & 102.2 \\
\hline $3^{\prime}$ & & 139.7 \\
\hline 4 & $10.60(\mathrm{~s}, 1 \mathrm{H})$ & \\
\hline $4^{\prime}$ & & 130.4 \\
\hline 5 & $7.03(\mathrm{~d}, 8.5,1 \mathrm{H})$ & 130.2 \\
\hline 6 & $6.89(\mathrm{~m}, 3.7,1 \mathrm{H})$ & 109.6 \\
\hline 7 & $6.82(\mathrm{dd}, 7.4,7.4,1 \mathrm{H})$ & 121.5 \\
\hline 8 & $6.97(\mathrm{~d}, 7.4,1 \mathrm{H})$ & 123.3 \\
\hline $8^{\prime}$ & & 129.5 \\
\hline $8^{\prime}$ & & 144.1 \\
\hline 9 & $4.56(\mathrm{~s}, 1 \mathrm{H})$ & 84.6 \\
\hline 10 & & 126.1 \\
\hline 11 & $7.22(\mathrm{~m}, 8.4,1 \mathrm{H})$ & 130.8 \\
\hline 12 & $6.65(\mathrm{~m}, 8.4,1 \mathrm{H})$ & 114.3 \\
\hline 13 & & 157.1 \\
\hline 14 & $6.65(\mathrm{~m}, 8.4,1 \mathrm{H})$ & 114.3 \\
\hline 15 & $7.22(\mathrm{~m}, 8.4,1 \mathrm{H})$ & 130.8 \\
\hline 16 & $9.28(\mathrm{~s}, 1 \mathrm{H})$ & \\
\hline 17 & $3.05(\mathrm{~s}, 3 \mathrm{H})$ & 56.4 \\
\hline 18 & $3.18(\mathrm{~s}, 3 \mathrm{H})$ & 50.9 \\
\hline
\end{tabular}


Table 3. ${ }^{1} \mathrm{H}$ and ${ }^{13} \mathrm{C}$ NMR Data for 3 in DMSO- $d_{6}{ }^{a}$

\begin{tabular}{lll}
\hline no. & $\delta 1 \mathrm{H}(\mathrm{m}, J \mathrm{~Hz})$ & $\delta^{13} \mathrm{C}$ \\
\hline 1 & & 144.2 \\
2 & & 150.7 \\
3 & & 170.2 \\
$3 \mathrm{a}$ & & 137.2 \\
4 & $11.62(\mathrm{~s}, 1 \mathrm{H})$ & \\
$4 \mathrm{a}$ & & 136.1 \\
5 & $7.42(\mathrm{~d}, 7.8,1 \mathrm{H})$ & 113.8 \\
6 & $7.19(\mathrm{dd}, 7.7,5.2,1 \mathrm{H})$ & 123.0 \\
7 & $7.36(\mathrm{dd}, 8.2,5.2,1 \mathrm{H})$ & 127.5 \\
8 & $7.90(\mathrm{~d}, 8.2,1 \mathrm{H})$ & 123.3 \\
$8 \mathrm{a}$ & & 139.1 \\
$8 \mathrm{~b}$ & & 122.2 \\
9 & $7.67(\mathrm{~s}, 1 \mathrm{H})$ & 143.5 \\
10 & & 124.8 \\
11 & $6.95(\mathrm{~m}, 8.7,1 \mathrm{H})$ & 132.7 \\
12 & $6.50(\mathrm{~m}, 8.7,1 \mathrm{H})$ & 115.1 \\
13 & $5.50(\mathrm{~m}, 8.7,1 \mathrm{H})$ & 159.2 \\
14 & $6.95(\mathrm{~m}, 8.7,1 \mathrm{H})$ & 115.1 \\
15 & 132.7 \\
16 & $9.35(\mathrm{~s}, 1 \mathrm{H})$ & \\
17 & $3.55(\mathrm{~s}, 3 \mathrm{H})$ & 59.5 \\
18 & $3.65(\mathrm{~s}, 3 \mathrm{H})$ & 51.8 \\
19 & & 167.3 \\
2 & & 167.1 \\
3 & & 131.8 \\
$3^{\prime}$ & & 119.2 \\
4 & $11.24(\mathrm{~s}, 1 \mathrm{H})$ & \\
4 & & 135.7 \\
5 & $7.35(\mathrm{~d}, 8.1,1 \mathrm{H})$ & 111.4 \\
6 & $7.11(\mathrm{dd}, 8.1,7.0,1 \mathrm{H})$ & 126.1 \\
7 & $7.02(\mathrm{~d}, 7.0,1 \mathrm{H})$ & 119.2 \\
8 & $7.37(\mathrm{~d}, 5.1,1 \mathrm{H})$ & 119.6 \\
$8^{\prime}$ & & 129.1 \\
$8^{\prime}$ & & 106.3 \\
\hline$a^{1} \mathrm{H} 400 \mathrm{MHz} ;{ }^{13} \mathrm{C} 100 \mathrm{MHz} ; 298 \mathrm{~K}$. & \\
\hline & & \\
\hline
\end{tabular}



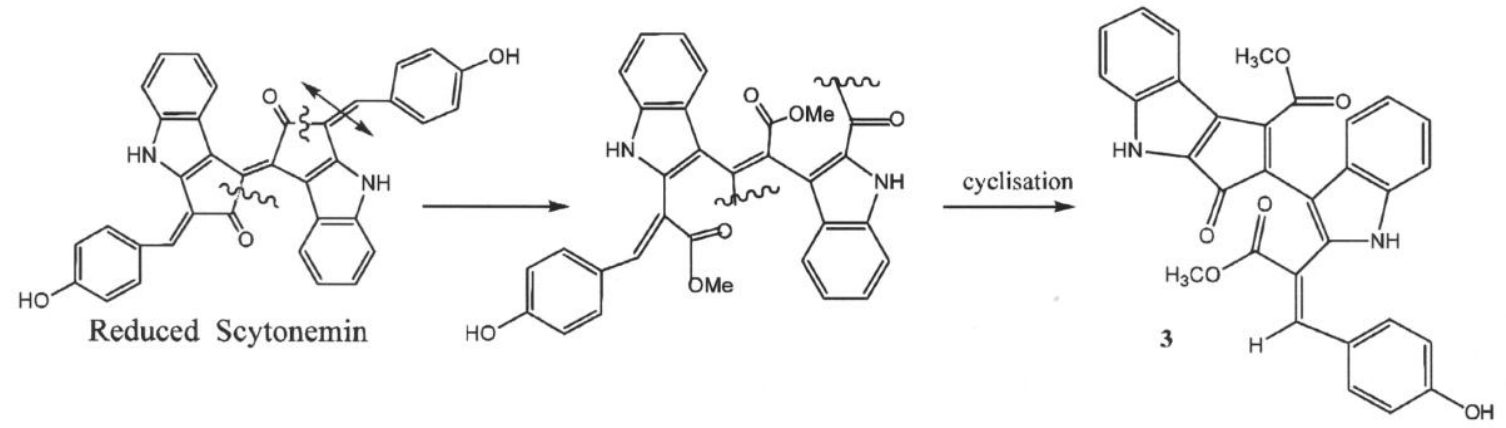

Fig. 1 

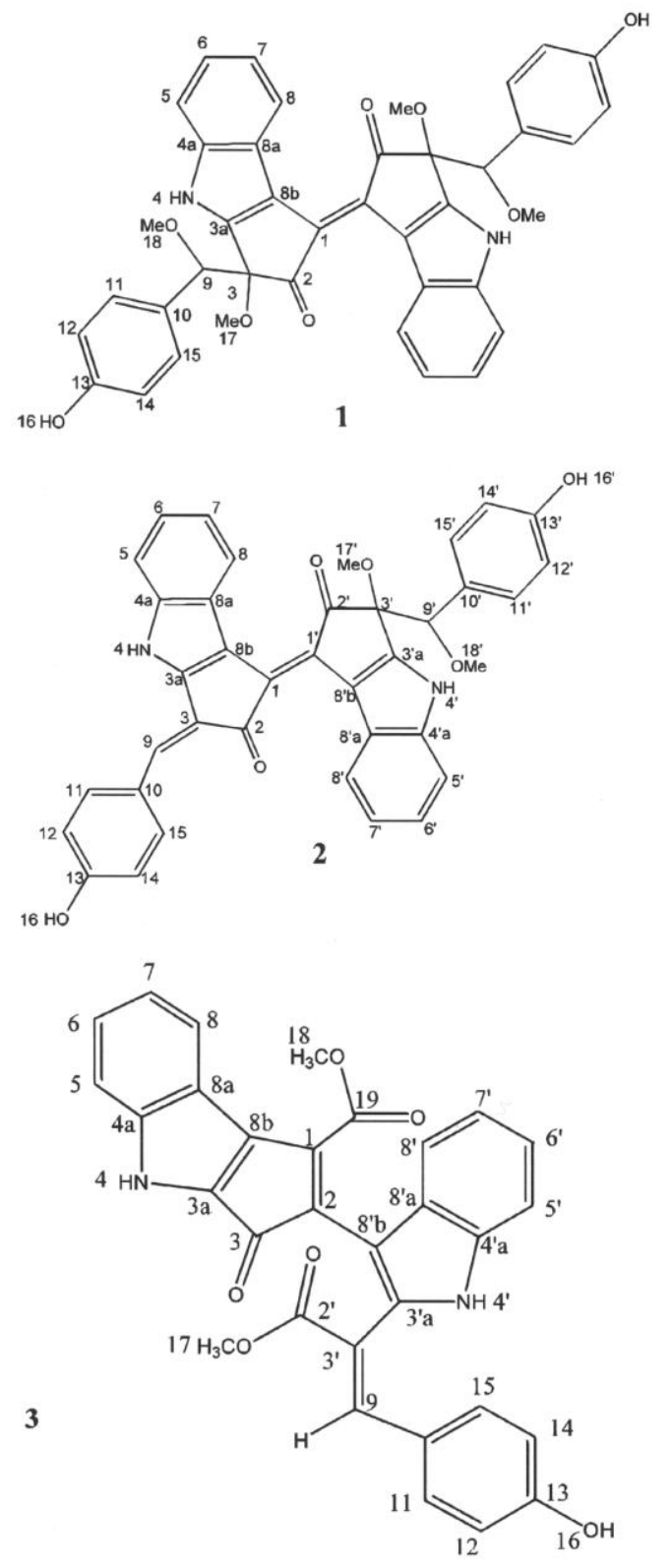